\title{
Pengaruh Model Pembelajaran Kooperatif Tipe STAD (Student Teams Achievement Division) Terhadap Hasil Belajar Siswa Materi Ciri-Ciri Makhluk Hidup
}

\author{
Kusno S. M. Kansil $1^{*}$, Ni Wayan Suriani² \\ 1,2Jurusan Pendidikan IPA, FMIPA, Universitas Negeri Manado \\ *e-mail: kusno.kansil@gmail.com
}

\begin{abstract}
Abstrak. Penelitian ini dilakukan untuk mengetahui pengaruh penggunaan model pembelajaran kooperatif tipe STAD terhadap hasil belajar siswa pada materi ciri-ciri makhluk hidup. Proses pembelajaran melalui model kooperatif STAD. Penelitian ini dilaksanakan di SMP Negeri 6 Baturapa Tahun Ajaran 2017-2018. Penelitian ini menggunakan metode eksperimen. Populasi dalam penelitian ini adalah seluruh siswa kelas VII yang terdiri 3 kelas. Pengambilan sampel dilakukan secara acak dan dipilih 2 kelas dengan jumlah masing-masing 25 siswa, kelas VIIA eksperimen dan kelas VIIB sebagai kelas kontrol. Data hasil belajar siswa dari kedua model pembelajaran diperoleh dari pretest dan posttest. Hasil penelitian menunjukkan bahwa pada uji perbedaan dua rerata (uji-t) pada taraf nyata 0,05 diperoleh $t_{\text {hitung }}=2,52679>t_{\text {tabel }}=$ 1,67722 sehingga menunjukkan bahwa rata-rata hasil belajar siswa yang diajar menggunakan model pembelajaran kooperatif tipe STAD lebih tinggi dibandingkan rata-rata hasil belajar siswa yang diajar menggunakan model konvensional. Kesimpulan dalam penelitian ini terdapat pengaruh model pembelajaran kooperatif tipe STAD terhadap hasil belajar siswa pada kelas VII SMP Negeri 6 Baturapa khususnya pada materi ciri-ciri makhluk hidup.
\end{abstract}

Kata kunci: STAD, hasil belajar, ciri-ciri makhluk hidup

\begin{abstract}
This study was conducted to determine the effect of using the STAD cooperative learning model on student learning outcomes in the material characteristics of living things. The learning process uses the STAD cooperative model. This research was conducted at SMP Negeri 6 Baturapa in the 2017-2018 academic year. This research is using experimental method. The population in this study were all students of class VII consisting of 3 classes. Sampling was done randomly and two classes were selected with 25 students each, class VIIA experiment and class VIIB as the control class. Student learning outcomes data from both learning models were obtained from the pretest and posttest. The results showed that the two-mean difference test (t-test) at the 0.05 level obtained $t_{\text {count }}=2.52679>t_{\text {table }}=1.67722$, thus indicating that the average learning outcomes of students taught using cooperative learning model type STAD were more higher than the average learning outcomes of students taught using conventional models. The conclusion in this study there is an effect of the cooperative learning model type STAD on student learning outcomes in class VII SMP Negeri 6 Baturapa, especially on the material characteristics of living things.
\end{abstract}

Keywords: STAD, learning outcomes, characteristics of living things

Diterima 26 Mei 2020 | Disetujui 19 Juni 2020 | Diterbitkan 30 Juni 2020

\section{PENDAHULUAN}

Pendidikan merupakan suatu hal yang sangat penting dan tidak dapat dipisahkan dari kehidupan seseorang.
Pendidikan mempunyai peran yang sangat strategis dalam meningkatkan kualitas sumber daya manusia dan upaya mewujudkan cita-cita bangsa Indonesia. 
Menyadari akan hal tersebut, pemerintah sangat serius menangani bidang pendidikan, sebab dengan sistem pendidikan yang baik diharapkan muncul generasi penerus bangsa yang berkualitas dan mampu menyesuaikan diri untuk hidup bermasyarakat, berbangsa dan bernegara. Maka untuk menghasilkan sumber daya manusia yang berkualitas, diperlukan modal dari hasil pendidikan itu sendiri.

Berdasarkan hasil observasi yang dilakukan peneliti di SMP Negeri 6 Baturapa, ternyata masih banyak siswa yang kurang aktif dalam kegiatan pembelajaran IPA Terpadu sehingga hasil belajar siswa tergolong rendah. Hal ini karena pelaksanaan kegiatan proses pembelajaran masih menggunakan model pembelajaran yang cenderung lebih berpusat pada guru, sehingga tidak ada hubungan timbal balik antara siswa dan guru ketika kegiatan proses belajar mengajar berlangsung.

Pembelajaran kooperatif tipe Student Teams Achievment Division (STAD) dapat membantu siswa dalam proses yang positif yaitu memacu kerja sama antara anggota kelompok sehingga meningkatkan hasil belajar siswa pada mata pelajaran IPA terpadu khususnya pada materi ciri-ciri makhluk hidup. Model pembelajaran kooperatif tipe STAD ini mempunyai ciri khas yaitu penyajian kelas, belajar secara berkelompok, kuis, nilai pengembangan dan penghargaan terhadap kelompok. (Anas, 2014).

Model pembelajaran kooperatif tipe STAD merupakan model pembelajaran kooperatif yang mengandung unsur kerjasama siswa dalam kelompok, tanggung jawab kelompok dalam pembelajaran individu dan penambahan skor dilakukan setelah kuis, dan antar kelompok dalam permainan yang edukatif. Jadi, setiap anggota kelompok harus memahami materi lebih dulu sebelum mengikuti kuis dan game. Dengan demikian, siswa tidak akan merasa bosan dan memperoleh manfaat yang maksimal dari segi keaktifannya (Millah, 2013).

\section{METODE PENELITIAN}

Penelitian ini bertujuan untuk membahas pengaruh model pembelajaran kooperatif tipe STAD (Student Teams Achievement Division) terhadap hasil belajar siswa materi ciri-ciri makhluk hidup. Pelaksanaan penelitian ini berlangsung pada tanggal 11 september 19 september yaitu pada semester genap tahun ajaran 2017/2018. Subjek dalam penelitian ini yaitu siswa kelas VII B yang berjumlah 25 orang sebagai kelas kontrol yang diajarkan menggunakan model pembelajaran konvensional dan siswa kelas VII A yang berjumlah 25 orang sebagai kelas eksperimen yaitu kelas yang diajarkan menggunakan model STAD. Metode yang digunakan adalah eksperimen semu atau quasi eksperimental dengan desain penelitian yaitu randommized control-grup pretestposttest (Suryabrata, 2012).

Instrumen yang digunakan dalam penelitian ini meliputi instrumen pembelajaran dan instrumen pengambilan data. Instrumen pembelajaran meliputi silabus, rencana pelaksanaan pembelajaran (RPP), lembar kerja siswa (LKS). Sedangkan instrumen pengambilan data meliputi instrument angket untuk mengetahui tingkat motivasi siswa dan tes untuk mendapatkan hasil belajar siswa yang berupa soal objektif.

Teknik pengumpulan data berawal dari observasi, kemudian dibuat perangkat pembelajaran yang akan digunakan dalam proses pembelajaran yaitu RPP, Silabus dan LKS, kemudian dilanjutkan dengan dilakukan pretest pada siswa kelas VII A sebagai kelas kontrol dan kelas VII B selaku kelas eksperimen, setelah itu diberi perlakuan yang berbeda pada setiap kelas dan tahap yang terakhir yaitu pemberian soal posttest kepada siswa kelas VII A dan VII B.

Teknik yang digunakan untuk analisis data pada penelitian dibagi menjadi 2 tahap, yaitu tahap awal dengan melakukan uji normalitas data dengan uji Lilliefors dan uji homogenitas serta tahap akhir dengan menggunakan uji hipotesis (uji t). 


\section{HASIL DAN PEMBAHASAN}

\section{Hasil Penelitian}

Data yang diambil adalah data dari hasil belajar siswa yang diperoleh dari pretest dan posttest dapat dilihat pada Tabel 1 untuk kelas eksperimen dan Tabel 2 untuk kelas kontrol.

Tabel 1. Ringkasan data hasil pretest dan posttest kelas eksperimen

\begin{tabular}{llll}
\hline \multirow{2}{*}{ Statistik } & \multicolumn{3}{c}{ Nilai statistik } \\
\cline { 2 - 4 } & Pretest & Posttest & Selisih \\
\hline Skor minimum & 15 & 53 & 38 \\
Skor & 40 & 98 & 58 \\
maksimum & & 1588 & 701 \\
Sum $\left(\sum\right)$ & 887 & 77.8 & 54.6 \\
Mean $(\bar{x})$ & 23.2 & 77.6 & \\
Varians $\left(\mathrm{S}^{2}\right)$ & 61.33 & 170.91 & 109.58 \\
\hline
\end{tabular}

Tabel 2. Ringkasan data hasil pretest dan posttest kelas kontrol

\begin{tabular}{llll}
\hline \multirow{2}{*}{ Statistik } & \multicolumn{3}{c}{ Nilai statistik } \\
\cline { 2 - 4 } & Pretest & Posttest & Selisih \\
\hline Skor minimum & 11 & 50 & 39 \\
Skor & 40 & 89 & 49 \\
maksimum & & & \\
Sum $\left(\sum\right)$ & 581 & 1727 & 1146 \\
Mean $(\bar{x})$ & 23.24 & 69.08 & 45.84 \\
Varians $\left(\mathrm{S}^{2}\right)$ & 78.32 & 79.35 & 1.03 \\
\hline
\end{tabular}

Uji normalitas Lilliefors dilakukan untuk mengetahui apakah data berdistribusi normal atau tidak. Suatu sampel dikatakan normal jika Lhitung < Ltabel. Dengan kriteria hipotesis: Terima $\mathrm{H}_{0}$ : sampel berasal dari populasi normal

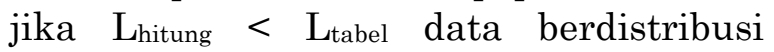
normal, dan Terima $\mathrm{H}_{1}$ : sampel berasal dari populasi tidak normal jika L Litung $>$ Ltabel data berdistribusi tidak normal, dapat dilihat pada nilai pretest kelas eksperimen berdistribusi normal yaitu dengan nilai $L_{\text {hitung }}=0,148853<\mathrm{L}_{\text {tabel }}=$ 0,1772 , dan nilai pretest kelas kontrol berdistribusi normal yaitu dengan nilai $\mathrm{L}_{\text {hitung }}=0,07075<\mathrm{L}_{\text {tabel }}=0,1772$.

Hasil analisis pengujian kesamaan (uji homogenitas) dua ragam dengan statistik uji $\mathrm{F}$ pada data pretest, menunjukan bahwa $F_{\text {hitung }}<\mathrm{F}_{\text {tabel }}$ atau 1,74 $<1,98$ sehingga terima $H_{0}: \sigma_{1}^{2}=\sigma_{2}^{2}$. Jadi, dapat dianggap bahwa varians dari kedua kelas yaitu kelas eksperimen dan kelas kontrol adalah homogen atau sama.
Data hasil pengujian hipotesis dengan uji t, pada taraf nyata $5 \%$ statistik uji tersebut jatuh dalam wilayah kritis, yaitu dengan nilai dapat dilihat pada Tabel 3 .

Tabel 3. Rangkuman hasil uji statistik parametrik atau uji-t

\begin{tabular}{llll}
\hline$t_{\text {hitung }}$ & $\mathrm{t}_{\text {tabel }}$ & $a$ & Kriteria \\
\hline 2.52679 & 1.67722 & 0.05 & $\begin{array}{l}\mathrm{t}_{\text {hitung }}> \\
\mathrm{t}_{\text {tabel }}\end{array}$ \\
\hline
\end{tabular}

Dari perhitungan pengujian hipotesis penelitian diperoleh thitung senilai 2,52679. Berdasarkan Tabel 3, distribusi uji-t pada $a=0,05$, maka diperoleh tabel senilai 1,67722. Disimpulkan bahwa terdapat pengaruh model pembelajaran kooperatif tipe STAD terhadap hasil belajar siswa SMP Negeri 6 Baturapa.

\section{Pembahasan}

Berdasarkan hasil penelitian yang dilaksanakan di SMP Negeri 6 Tondano pada semester genap tahun ajaran $2017 / 2018$ di kelas $\mathrm{VII}_{\mathrm{A}}$ diajar menggunakan model pembelajaran kooperatif tipe STAD dan model pembelajaran konvensional yang diajar pada kelas $\mathrm{VII}_{\mathrm{B}}$ dengan menggunakan materi ciri-ciri makhluk hidup menunjukkan bahwa terdapat perbedaan hasil belajar. Pada kelas eksperimen, materi ciri-ciri makhluk hidup, secara umum menunjukkan adanya pengaruh positif yang nyata akan pengunaan perlakuan tersebut terhadap peningkatan hasil belajar dari para siswa tersebut (Sugiyono, 2013)

Hal ini ditunjukkan dengan ratarata hasil tes yang diberikan kepada kedua kelas dimana skor pretest kelas eksperimen adalah 23,2 yang kemudian mengalami peningkatan pada skor posttest 77,8 dari skor ideal 100 , dan untuk kelas kontrol di peroleh rata-rata nilai pretest adalah 23,24 sedangkan skor posttest adalah 69,08 dari skor ideal 100, dan kemudian rata-rata selisih posttespretest untuk kelas eksperimen adalah 54,6 sedangkan untuk kelas kontrol di peroleh 45,84 dari 25 siswa untuk kelas eksperimen dan 25 siswa untuk kelas kontrol. 
Hal ini memperlihatkan selisih peningkatan skor hasil pretest dan posttest untuk kelas eksperimen lebih besar dari pada selisih peningkatan skor hasil pretest dan posttest untuk kelas kontrol. Pada pengujian hipotesis dengan menggunakan uji perbedaan dua ratarata, di peroleh hasil dimana thitung $>t_{\text {tabel, }}$ sehingga $\mathrm{H}_{0}$ ditolak dan $\mathrm{H}_{1}$ diterima. Model pembelajaran kooperatif tipe STAD lebih baik dibandingkan rata-rata hasil belajar siswa pada materi ciri-ciri makhluk hidup dengan menggunakan model pembelajaran konvensional.

Pada model pembelajaran kooperatif tipe STAD sangat baik karena pembagian kelompok-kelompok kecil dengan memperhatikan keberagaman anggota kelompok merupakan sebagai wadah siswa bekerjasama dan memecahkan suatu masalah melalui interaksi sosial dengan teman sebayanya, penggunaan model pembelajaran STAD terjadi beberapa perubahan pada siswa diantaranya, siswa lebih aktif dalam mengikuti kegiatan belajar, semangat belajar yang tinggi dan kinerja tiap kelompok yang baik tanpa membedabedakan teman belajar (Nugroho, 2013)

Pembelajaran kooperatif tipe STAD, bekerja dalam kelompok sehingga siswa dapat menumbuhkan kemauan kerja sama, berpikir kritis, termotivasi, bertanggung jawab terhadap kelompok (Wardana, 2017).

Berdasarkan hasil analisis data di atas dapat dilihat bahwa rata-rata hasil belajar kelas eksperimen lebih tinggi dibandingkan dengan kelas kontrol, sehingga dapat ditarik sebuah kesimpulan bahwa rata-rata hasil belajar siswa yang diajarkan dengan mengunakan model pembelajaran kooperatif tipe STAD (Student Teams Achievement Division) lebih baik dibandingkan rata-rata hasil belajar siswa pada materi ciri-ciri makhluk hidup dengan menggunakan model pembelajaran konvensional.

\section{KESIMPULAN}

Berdasarkan hasil penelitian dan pembahasan yang telah diuraikan maka dapat disimpulkan bahwa hasil belajar siswa yang diajarkan dengan menggunakan model pembelajaran kooperatif tipe STAD lebih tinggi dibandingkan dengan hasil belajar siswa yang menggunakan model pembelajaran konvensional pada materi ciri-ciri makhluk hidup dan mempunyai pengaruh terhadap hasil belajar siswa.

\section{DAFTAR PUSTAKA}

Anas. (2014). Mengenal Metode Pembelajaran. Pasuruan: CV. Pustaka Hulwa.

Millah, I. (2013). Pengaruh Penerapan Model Pembelajaran Kooperatif Tipe TGT (Team Games Tournament) Terhadap Prestasi Belajar Siswa Kelas X SMA Laboratorium UM Pada Materi Hidrokarbon. Skripsi: Universitas Negeri Malang.

Nugroho, D. R. (2013). Penerapan Model Pembelajaran Kooperatif Tipe TGT (Team Games Tournament) Terhadap Motivasi Siswa. Jurnal Pendidikan Olahraga Dan Kesehatan Universitas Negeri Surabaya, 1(1), 161-165.

Sugiyono. (2013). Statistika Untuk Penelitian. Bandung: Alfabeta.

Suryabrata. (2004). Metodologi Penelitian. Jakarta: Raya Grafindo Persada.

Wardana, I. (2017). Penerapan Model Pembelajaran Kooperatif Tipe Student Team Achievment Division (STAD) Untuk Meningkatkan Hasil belajar Siswa Kelas XI IPA Avogadro SMA Negeri 2 Pangkajene. Jurnal Pendidikan Kimia, 18(2), 76-84. 